\author{
LiLIANA KaLITA \\ Uniwersytet Gdański
}

iD

ORCID https://orcid.org/0000-0002-6025-2643

\title{
POSTAWY KONTESTACYJNE POKOLENIA NEXT (STОР! ИЛИ ДВИЖЕНИЕ БЕЗ ОСТАНОВОК IRINY BOGATYRIEWEJ)
}

\author{
EXPRESSIONS OF PROTEST BY THE “NEXT” GENERATION \\ (IRINA BOGATYREVA'S OFF THE BEATEN TRACKS: \\ STORIES BY RUSSIAN HITCHHIKERS)
}

This paper examines Russia's "Next" generation and its expressions of anti-consumerist protest, which stem from a fascination with the American Beat Generation. Criticism of the consumerist lifestyle prompts the protagonists of Bogatyreva's prose to seek an alternative, especially through hitchhiking, which provides the opportunity to become closer to oneself and others. Communion with nature and a turn towards Eastern Mysticism become important elements of these new styles of existence. The nature of the rebellion of the "Next" generation is primarily psychological, with an emphasis on expanding one's own awareness, as well as social, underpinned by the dream of creating a society based on anti-capitalist ideals.

Keywords: protest, the "Next" generation, contemporary Russian prose, self-knowledge, Bogatyreva

ОСПАРИВАНИЕ ДЕЙСТВИТЕЛЬНОСТИ ПРЕДСТАВИТЕЛЕЙ ПОКОЛЕНИЯ NEXT (STOP! ИЛИ ДВИЖЕНИЕ БЕЗ ОСТАНОВОК ИРИНЫ БОГАТЫРЕВОЙ)

Предметом анализа в предлагаемой статье является протестное отношение поколения next к действительности, базирующей на идеях потребления. 
Контекстом для оспаривающих тенденций является американская субкультура битников. Критическое отношение к консьюмеризму приводит молодых людей к поискам альтернативного стиля жизни - прежде всего он сводится к бродяжничеству как возможности познания собственного «я» и другого человека. Важной составляющей альтернативных форм экзистенции является контакт с природой и обращение к восточному мистицизму. Бунт молодого поколения имеет прежде всего психологический (расширение собственного сознания) и социальный (изменение социальных идеалов) характер.

Ключевые слова: оспаривание, поколение next, современная русская проза, самопознание, Богатырева

Pomiędzy egzystencją człowieka a politycznymi, społecznymi, gospodarczymi czy kulturowymi jej uwarunkowaniami istnieje ścisła korelacja. O ile w epoce przednowoczesnej różnica w funkcjonowaniu kolejnych pokoleń nie była tak łatwo dostrzegalna, o tyle obecnie, za sprawą opartego na technologicznym przyspieszeniu rozwoju cywilizacyjnego, w społeczeństwach ponowoczesnych mamy do czynienia, jak twierdzą badacze zjawiska, z kilkoma pokoleniami, które „mają swoje własne słowniki i konstelacje symboli, kategorie poznawcze i wzorce uczuć, formy komunikacji i modele przyjaźni, mity i projekty przyszłości. To już nie tylko odmienne środowiska czy warstwy społeczne - to odmienne

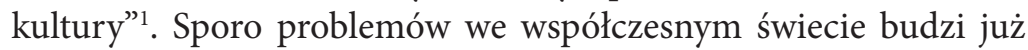
samo przyporządkowanie kogoś do określonego pokolenia, jak bowiem w 2016 roku pisał jeden z publicystów,

co generacja, to generalizacja — rok urodzenia to jeszcze za mało, żeby do konkretnego pokolenia kogokolwiek zaliczyć. Albo żeby bezbłędnie tę osobę scharakteryzować. Poza wszystkim trudno na przestrzeni ostatnich 16 lat odszukać taki moment dziejowy, który przekreślałby grubą kreską to, co było przedtem, od tego, co nastąpiło później. To zadanie dla historyków, i to dopiero takich, którzy przyjdą po nas i spojrzą na nasze czasy z dystansu².

${ }^{1}$ G. Godlewski, Animacja i Antropologia, w: G. Godlewski i in. (red.), Animacja Kultury. Doświadczenie i przyszłość, Instytut Kultury Polskiej UW, Warszawa 2002, s. 60.

${ }^{2}$ Tumblr, Milenialsi, generacja Z... Skąd wiadomo, do którego pokolenia się nale $\dot{z} y$ ?, https://www.polityka.pl/tygodnikpolityka/ludzieistyle/1654918,1,milenialsi-generacja-z-skad-wiadomo-do-ktorego-pokolenia-sie-nalezy.read (2.08.2020). 
Powszechnie w literaturze przedmiotu wyróżnia się pokolenie Baby Boomers, obok którego istnieją pokolenia X, Y, Z ${ }^{3}$. W publikacjach dotyczących problematyki społecznej można również natknąć się na pojęcie milenialsi (również „starsi” i „młodsi” milenialsi), stosowane na określenie pokolenia urodzonego pomiędzy 1980 a 2000 rokiem. Generacja ta zwana jest również pokoleniem next lub Y, a wśród cech ją charakteryzujących wymienia się m.in. pewność siebie, hedonizm, otwartość i tolerancyjność oraz komunikację za pomocą social media ${ }^{4}$.

Procesy dokonujące się w społeczeństwie pod wpływem transformacji politycznych czy gospodarczych nie pozostają bez wpływu na literaturę. Nowi bohaterowie, przedstawiciele zmieniającej się rzeczywistości stają się przedmiotem artystycznego oglądu, wzbogacając literacki portret danego społeczeństwa. Jest to szczególnie widoczne w krajach, w których na przełomie lat 80. i 90. doszło do przekształceń systemowych, skutkujących odejściem od centralnego planowania, na rzecz gospodarki wolnorynkowej, czyli m.in. w Polsce i w Rosji. To z kolei zrodziło nowych bohaterów literackich: bohaterem okresu przejściowego był tzw. Nowy Rosjanin, utożsamiany z drapieżnym etapem powstawania kapitalizmu (proza m.in. Wiktora Pielewina, Oksany Robski, Andrieja Dmitriewa, Aleksandry Maryniny, Władimira Tuczkowa), i dość dobrze już opisany w refleksji historycznoliterackiej (teksty autorstwa Katarzyny Dudy, Beaty Pawletko, Anny Skotnickiej,

\footnotetext{
${ }^{3}$ Generacjom tym przyporządkowane są określone lata urodzenia ich przedstawicieli, choć warto pamiętać, że granice te są dość płynne. I tak Baby Boomers to lata 1946-1969, Generation X: 1970-1979, Generation Y: 1980-1994, Generation Z: urodzeni po roku 1990. Zob. S. Stachowska, Oczekiwania przedstawicieli pokolenia Y wobec pracy i pracodawcy, "Zarządzanie Zasobami Ludzkimi” 2012, nr 2 (85), s. 33-56, http://www.ipiss.com.pl/wp-content/uploads/downloads/2015/01/ZZL_2-2012_Stachowska-S_33-56.pdf (2.08.2020); M. Walków, Pokolenia na rynku pracy $w$ Polsce - kim sa baby boomers, X, Y i C?, https:// businessinsider.com.pl/rozwoj-osobisty/kariera/millenials-pokolenie-X-y-z-ibaby-boomers-kim-sa-na-rynku-pracy/6e53lmr (2.08.2020).

${ }^{4}$ P. Kamińska, 7 zasad strategii marketingowej, czyli jak skutecznie poskromić milenialsów, http://adnext.pl/onas/7-zasad-strategii-marketingowej-czyli-jakskutecznie-poskromic-milenialsow-2/ (2.08.2020).
} 
Aleksandry Zywert ${ }^{5}$ ), który z czasem ustąpił nieco miejsca bohaterowi korporacyjnemu (proza m.in. Jewgienija Griszkowca, Germana Sadułajewa, Andrieja Doncowa), modelowanemu według zachodnich wzorców, choć z rosyjską (szczerą, a jednocześnie niezdyscyplinowaną) duszą, również podlegającemu krytycznej refleksji (m.in. teksty Katarzyny Dudy, Liliany Kality, Aleksandry Zywert $\left.^{6}\right)$.

Obecność w najnowszej literaturze rosyjskiej pokolenia next odnotowała Alicja Wołodźko-Butkiewicz, podkreślając, że cechą tej generacji jest

demonstracyjne odwracanie się od ideologii, problemów państwa i polityki - chyba, że rzutują na ich własny los, jak w przypadku weteranów wojny czeczeńskiej. [...] Dystansuje się też ono od gier postmodernistycznych, po-

${ }^{5}$ Problematyce tzw. Nowych Rosjan poświęcone są m.in. następujące teksty: K. Duda, „Nowi Rosjanie” i statystyczny obywatel. Współczesna Rosja w literaturze popularnej (Oksana Robski i Wiktoria Tokariewa), w: tejże (red.), Kultura rosyjska w ojczyźnie i diasporze. Ksiega jubileuszowa dedykowana profesorowi Lucjanowi Suchankowi, t. 2, Wydawnictwo Uniwersytetu Jagiellońskiego, Kraków 2008, s. 201-210; tejże, Nowy Rosjanin w przestrzeni miasta-metropolii, „Politeja” 2015, nr 39, s. 329-344; B. Pawletko, "Nowi Rosjanie” w krzywym zwierciadle literatury (na przykładzie prozy Władimira Tuczkowa), w: J. ŁawnikowskaKoper, L. Rożek (red.), Antropologia kultury mieszczańskiej, Akademia im. Jana Długosza w Częstochowie, Częstochowa 2016, s. 193-204; A. Skotnicka, Образ „нового русского” в современной прозе, w: K. Chrobak i in. (red.), Wielkie tematy kultury $w$ literaturach słowiańskich. Pieniądz, Wydawnictwo Uniwersytetu Wrocławskiego, Wrocław 2009, s. 225-233; A. Zywert, Literacki obraz Nowych Rosjan, „Roczniki Humanistyczne” 2018, t. 66, z. 7, s. 125-138.

${ }^{6} \mathrm{~W}$ tym kontekście przedmiotem analiz jest przede wszystkim twórczość Siergieja Minajewa. Zob. K.A. Duda, „...i utraciłem wiarę $w$ ostatni bastion duchowości”. Siergiej Minajew - „Duchless. Opowieść o nieprawdziwym człowieku”, w: tejże, Szkice o prozie rosyjskiej XXI wieku. Ulicka, Szyszkin, Pielewin, Minajew, Sienczyn, Kuricyn, Starobiniec..., Księgarnia Akademicka, Kraków 2017, s. 121-149; L. Kalita, Kreowanie własnego wizerunku przedstawiciela rosyjskiej klasy średniej (na materiale powieści Siergieja Minajewa „The Телки. Повесть о ненастоящей пюбви”), w: J. Mampe, Ł. Owczinnikowa (red.), Socjolingwistyczne badania $w$ teorii i praktyce. Ujęcie interdyscyplinarne, t. 1, Wydawnictwo Uniwersytetu Gdańskiego, Gdańsk 2014, s. 47-56; A. Zywert, Jak się bawiq nieprawdziwi ludzie? (Sergiej Minajew, „Duchless”), w: L. Kalita (red.), Czas wolny, rozrywka, używi w najnowszej literaturze rosyjskiej, Wydawnictwo Uniwersytetu Gdańskiego, Gdańsk 2018, s. 53-68. 
chłonięte przede wszystkim codziennością, sprawami grup środowiskowych, poszukiwaniem własnego miejsca pod słońcem ${ }^{7}$.

Warszawska badaczka w gronie pisarzy pokolenia next sytuuje Irinę Dienieżkinę, Siergieja Szargunowa, Olega Pawłowa, Arkadija Babczenkę czy Aleksieja Szorochowa. Wydaje się, że do tego grona dołączyć można Irinę Bogatyriewą (ur. w 1982 r.), absolwentkę Instytutu Literackiego im. Gorkiego, autorkę opowiadań i powieści, laureatkę nagrody „Studencki Booker” (w 2016 roku za powieść Кадын), której proza tłumaczona była m.in. na angielski, francuski, chiński, szwedzki, włoski i arabski. W 2005 roku Bogatyriewa napisała swój debiutancki utwór - Stop! или Движение без остановок - oparty na jej własnych doświadczeniach, w którym zawarła ocenę konsumpcyjno-korporacyjnego stylu życia dokonaną przez pokolenie dwudziestolatków, a jednocześnie propozycję alternatywy w postaci zwrócenia się ku egzystencji propagowanej w latach 60 . XX wieku przez kontestacyjne ruchy beatników i hippisów. Kiriłł Ankudinow, odnotowując pojawienie się na scenie literackiej nowej pisarki, skonstatował, że jej utwór „czyta się z zainteresowaniem nie tylko ze względu na jego warstwę społeczną (egzotyczną i kolorową) - nie tylko jako 'szkic fizjologiczny', ale jako dobrą — głęboką i emocjonalnie zniuansowaną - prozę" ${ }^{\prime \prime}$. Strategia narracyjna pisarki nie jest sprawą łatwą do uchwycenia. Krytyka zalicza Bogatyriewą do takich nurtów stylistycznych i gatunków jak realizm magiczny, słowiańskie fantasty czy heroiczny epos, jednak zdaniem Anny Żuczkowej rosyjska autorka nie realizuje w pełni żadnego

\footnotetext{
${ }^{7}$ A. Wołodźko-Butkiewicz, Od pieriestrojki do laboratoriów netliteratury. Przemiany we współczesnej prozie rosyjskiej, Studia Rossica, Warszawa 2004, s. 317.

${ }^{8}$ Tekst Bogatyriewej AвmoSTOP był wydany po raz pierwszy w formie książkowej w 2008 roku przez wydawnictwo „Eksmo” w serii „Powieść pokolenia next”. Jeden rozdział opowieści był opublikowany w 2007 roku w pierwszym numerze czasopisma „День и ночь”, a czasopiśmienniczy wariant całości w piątym numerze czasopisma „Октябрь” również w 2007 roku - w obu wypadkach utwór nosił autorski tytuł Stop! или Движение без остановок.

${ }^{9}$ К. Анкудинов, Чертово поле экспериментов, „ВЗГЛЯД.РУ”, 15.07.2007, https://vz.ru/culture/2007/7/15/94305.html (4.08.2020).
} 
z tych gatunków, a „wykorzystanie elementów folklorystycznych w tekstach pisarki sprowadza się do ich ilustracyjno-ornamentalnej funkcji”" ${ }^{10}$. Eklektyczny charakter utworów Bogatyriewej, przejawiający się w synkretyzmie gatunkowym, a także obecność aluzji kulturowych i literackich oraz odniesienia do filozofii czy mitologii zbliżają pisarkę, z jednej strony, do nurtu literatury postmodernistycznej, z drugiej jednak - realistyczny sposób kreowania postaci czy wątków fabularnych pozwalałby sytuować artystkę w obrębie nowego realizmu ${ }^{11}$.

Kontestacyjny aspekt zachowania młodzieży, będącej przedmiotem obserwacji Bogatyriewej w omawianym tu utworze, polega na przyjęciu postawy „odmowy uczestnictwa w zastanej rzeczywistości” i podjęciu próby „tworzenia małych społeczności, kształtujących nowe style życia, nowe formy międzyludzkich kontaktów, niemożliwe do urzeczywistnienia w ramach 'normalnych' układów społecznych"12. Bohaterów analizowanej opowieści można nazwać melancholijnymi outsiderami, to dzieci przełomu, które nie zdążyły zasmakować euforii dokonujących się w kraju zmian, gdyż byli na to zbyt młodzi, a teraz - wchodząc w dorosłe i samodzielne życie - doświadczają negatywnych skutków konsumpcyjnego pędu $\mathrm{ku}$ coraz to nowym przyjemnościom i wyzwaniom, stawianym przez gospodarkę kapitalistyczną. Życie w ponowoczesnym społeczeństwie sprawia, że człowiek ulega „typowym, niekorzystnym dla jego podmiotowości, presjom i mechanizmom typu alienacyjnego" ${ }^{13}$, co w efekcie przyczynia się do jego zubożenia duchowego

${ }^{10}$ А.В. Жучкова, Богатырская проза И. Богатыревой. Эклектика жанра, „Вестник славянских культур” 2018, t. 50, http://www.vestnik-sk.ru/russian/ archive/2018/tom-50/zhuchkova (4.08.2020).

${ }^{11}$ Problematyka stylistycznych cech tekstów Bogatyriewej zasługuje na odrębne omówienie, które wykracza poza problematykę niniejszego artykułu, więc ograniczamy się jedynie do zasygnalizowania problemu.

${ }^{12}$ A. Jawłowska, Drogi kontrkultury, Państwowy Instytut Wydawniczy, Warszawa 1975, s. 7.

${ }^{13} \mathrm{~J}$. Szmyd, Nowoczesny konsumpcjonizm - zmiana kondycji ludzkiej i jakości życia. Wyzwania społeczne i pedagogiczne, „Kultura - Przemiany - Edukacja” 2017, t. 5, s. 20. 
i redukcji jego emocjonalno-intelektualnych możliwości. Poczucie znajdowania się na rozstaju dróg, które boli i ciąży cechuje bohaterów Bogatyriewej. Nie należą oni do Nowych Rosjan, mogących poszczycić się willą wzdłuż szosy Rublowo-Uspienskiej, ani do korporacyjnych yuppies, wydających zarabiane $\mathrm{w}$ rodzimych filiach zachodnich firm pensje na modne gadżety i lansowany w mediach styl życia, którego nieodłącznym elementem są używki, bywanie w prestiżowych lokalach i kreowanie własnego wizerunku w portalach społecznościowych. Najbliżej im, jak się wydaje, do bohaterów prozy Iriny Dienieżkiny $\mathrm{z}$ ich beztroskim życiem na krótkoterminowych kontraktach, ale i z niewypowiadaną wprost tęsknotą za stabilizacją, autentycznymi relacjami i choćby minimalnie sprecyzowanymi celami.

Analizowany utwór Bogatyriewej zwraca uwagę swoim tytułem, w którym zastosowano jednocześnie alfabet łaciński i rosyjski. Pierwszy wyraz tytułu to z jednej strony nawiązanie do nieformalnego określania autostopu jako środka transportu, a więc sugestia tematyki utworu, $\mathrm{z}$ drugiej natomiast - w kontekście całości fabuły - wyrażenie pozycji ideowej protagonistki i jej pokolenia, negacja rzeczywistości, w której przyszło im żyć. Druga część tytułu to potwierdzenie tematyki utworu, związanej z wiecznym ruchem jako ideałem egzystencji, będącej alternatywą dla lansowanego w społeczeństwie modelu człowieka sukcesu - zwykle mieszkańca wielkiego miasta, którego normy kulturowo-społeczne wiążą z określonym miejscem, wyznaczając mu $\mathrm{z}$ reguły niezmienną $\mathrm{w}$ nim pozycję, czyli określona (wyrażona $\mathrm{w}$ formie neutralnej $\mathrm{w}$ przeciwieństwie do zastosowanego „stop!”) propozycja budowania własnej tożsamości w oparciu o wzorce zaczerpnięte z amerykańskiej kultury lat 50. XX wieku, której symbolem stało się pokolenie Beat Generation i osoba Jacka Kerouaca, autora $W$ drodze (On the Road, 1957), z którym, jak zauważa Phoebe Taplin, łączy Rosjan „wspólne poczucie odległości”"14. Sygnałem intertekstualnego odniesienia do kontrkulturowego zjawiska, jakim byli beatnicy, jest

\footnotetext{
${ }^{14}$ P. Taplin, The Russian Kerouacs: Irina Bogatyreva's guide to hitchhiking, „The Calvert Journal”, 20.08.2013, https://www.calvertjournal.com/articles/ show/1350/rise-of-the-russian-kerouacs-hitchhiking (5.08.2020).
} 
otwierający tekst Bogatyriewej swojego rodzaju manifest pokolenia, w którym czytamy:

Нас много. Мы - точки, разбросанные по дороге, романтические последователи гуру Керуака, мы братья одного ордена, и на нашем гербе можно вывести: „In via veritas” или проще: „Дорога всегда права”. У нас разные цели, разные маршруты, но все мы едины в своем ощущении: только здесь, на дороге, мы становимся свободными ${ }^{15}$.

Odwołania do idei bitników, urzeczenie „pędem, przemieszczaniem się, specyficznie pojmowaną wolnością" ${ }^{16}$ oraz potrzeba eksponowania własnego "Ja" staną się zatem naturalnym kontekstem interpretacyjnym opowieści Bogatyriewej. Autorka buduje więc most pomiędzy pokoleniami, które dzieli pół wieku, przypominając pewne idee w odmiennym geopolitycznym kontekście ${ }^{17}$.

Protagonistką i jednocześnie narratorką opowieści jest dwudziestokilkuletnia Miełkaja. To z jej perspektywy obserwujemy byt lokatorów mieszkania na Jakimance, wynajmowanego przez jego właściciela - Romę - przyjezdnym, którzy próbują urządzić się w stolicy. Najczęściej są to studenci lub artyści, dla których typowa jest sytuacja egzystencjalnego niezakotwiczenia - pracują dorywczo, pozbawieni są rodzinnego wsparcia ekonomicznego i emocjonalnego, znajdują się w większości w okresie liminalnym: na granicy młodzieńczości i dorosłości. Ich stosunek do rzeczywistości jest niejednorodny - waha się od akceptacji i próby znalezienia swojego miejsca w zastanych strukturach społecznych, co ma się dokonać poprzez ciężką pracę i oszczędne gospodarowanie środ-

${ }^{15}$ И. Богатырева, Stop! или Движение без остановок. Журнальный вариант, https://royallib.com/book/bogatireva_irina/Stop_ili_dvigenie_bez_ostanovok_gurnalniy_variant.html (5.08.2020). Dalej cytuję według tego wydania.

${ }^{16}$ C. Prasek, Złota młodzież PRL i jej obraz w literaturze i filmie, Bellona, Warszawa 2010, s. 32.

17 Odpowiednikiem kontrkultury bitników w ZSRR czasów „odwilży” była w pewnym stopniu subkultura tzw. stiliagów, zobrazowana np. w filmie Walerija Todorowskiego z 2008 roku pod takim właśnie tytułem. Nie odegrała ona jednak tak kulturowej i ideowej roli, jak ruch amerykański, który zaowocował tekstami m.in. Jacka Kerouaca, Allena Ginsberga i Williama S. Burroughsa. 
kami materialnymi (pianistka Sońka Muginstein), do nienawiści i chęci zemsty na bogatych mieszkańcach Moskwy za pozostawanie na marginesie, połączone z zazdrością o zajmowaną wysoką pozycję (artysta Tola). Pomiędzy tymi skrajnościami sytuuje się postawa większości - zaprawione poczuciem goryczy przekonanie o byciu na dole drabiny społecznej, a opuszczenie jej będzie możliwe wyłącznie w wyniku korzystnego splotu okoliczności, którego nie należy przeoczyć, a nie na skutek własnej sprawczości. Jednocześnie jest to jedyna rzeczywistość, jaka jest im dana, co znajdzie odzwierciedlenie w słowach protagonistki: „Тот мир, что за окнами Якиманки, - этот мир неоновый и глянцевый, и если бы меня даже что-то в нем не устраивало, откуда мне взять другой”.

Moskwa, do której bohaterowie urodzeni około połowy lat 80 . $\mathrm{XX}$ wieku, a więc formalnie należący do pokolenia next, przyjechali z prowincji w nadziei na lepsze życie, zweryfikowała ich oczekiwania i choć nadal pozostaje miejscem szans i możliwości, to jednocześnie jawi się im jako pajęcza sieć, która wciąga i pochłania żyjących w niej ludzi, jest pełna powierzchownego blichtru i wystawionego na pokaz teatralnego manifestowania bogactwa i radości (scena przyjęcia u Nowych Rosjan). Jest to przestrzeń uprzedmiotawiania ludzi, w której żyć można jedynie z dnia na dzień w oczekiwaniu na śmierć, to miasto - Moloch, które nigdy nie zasypia, jest wiecznie nienasycone i żądne kolejnych ofiar; zarówno praca, jak i aktywności w czasie wolnym stają się w tej rzeczywistości pułapką, ograniczającą wolność człowieka i modelującą go według jednakowych standardów.

Jeśli przedstawicieli amerykańskiej grupy Beat Generation określa się „zmarnowanym pokoleniem lat $50 . "{ }^{18}$, to bohaterów opowieści Bogatyriewej ze względu na to, że jest to pierwsze pokolenie czasów transformacji, wychowane już nie na ideałach sowieckich i słabo pamiętające przemiany gospodarcze lat 90 . XX wieku, moż-

${ }^{18} \mathrm{~K}$. Jesiotr, „W drodze” na Zachód. Między metafizyczną wędrówką Jarosława Markiewicza a deliryczna podróżą Wieniedikta Jerofiejewa, czyli o związkach literatury pisarzy byłego bloku wschodniego z twórczościa "pobitego pokolenia” Ameryki, https://depot.ceon.pl/bitstream/handle/123456789/15814/Katarzyna\%20Jesiotr.pdf? sequence $=1$ \&isAllowed $=y(5.08 .2020)$. 
na nazwać pokoleniem melancholików, mających świadomość utraty szans, które mieli ich poprzednicy i następcy. Doświadczają oni często uczucia nostalgii za przeszłością, jednak nie jest to tęsknota za dawnym ustrojem politycznym i jego ograniczeniami, ale za funkcjonującym pod jego powierzchnią bogactwem zjawisk kulturowych, przede wszystkim muzyki niosącej ważny i wartościowy przekaz o znaczeniu wolności w życiu człowieka, tęsknota za wspólnymi ideami, w oparciu o które można było kształtować własną tożsamość. Obecnie swoim zagubieniem i niewiarą w możliwość oddziaływania na otoczenie (kompensują sobie to prowokacyjnymi gestami, jak np. wyprowadzanie na spacer żelazka zamiast psa) młodzież pokolenia next przypomina nieco tradycyjny rosyjski typ tzw. zbędnych ludzi.

Współcześni zbędni ludzie - młodzi Rosjanie, podobnie jak ich XIX-wieczni przodkowie, zostali spisani na straty, ponieważ ich życie zaczęło ograniczać się do biernej, pustej egzystencji zamiast do aktywnego uczestnictwa w kreowaniu otaczającej rzeczywistości. Nie umieją wtopić się w zglobalizowaną masę. Charakteryzuje ich pasywność, bezcelowość i bezsensowność życia

- konstatuje Katarzyna Duda, podkreślając jednocześnie, że bohaterowie współczesnych powieści pokoleniowych przyjmują często postawę ucieczki — w przypadku np. bohaterów Duchless (Дyxless, 2008) Siergieja Minajewa jest to ucieczka w hedonistyczne przyjemności ${ }^{19}$. Obawy, wynikające $\mathrm{z}$ niestabilnej sytuacji życiowej, i brak jasno sformułowanych zasad pozwalających budować sens własnej egzystencji stają się kluczowym elementem tożsamości pokolenia next, zmuszając ich do kształtowania jej w zależności od sytuacji doraźnych, ich tożsamość jest więc płynna i wymagająca nieustannego konfrontowania z rzeczywistością. Szukając punktów odniesienia, protagonistka utworu porównuje swoje pokolenie z pokoleniem wcześniejszym - starszego rodzeństwa, $\mathrm{z}$ goryczą podkreślając odczuwaną wobec nich zazdrość:

Ваша жизнь давно состоялась, а моя зависла в вечной к вам тяге. О время, как странно ты выбираешь судьбы! Где справедливость, если кажется,

${ }^{19}$ K.A. Duda, Szkice o prozie rosyjskiej XXI wieku..., s. 125. 
что все хорошее прошло, а на век твоего поколения досталось выскребать подгорелые остатки?

Symbolem ideałów pokolenia starszych braci stają się w omawianej opowieści rockmeni czasów pierestrojki (Borys Griebienszczikow, Wiktor Coj, Aleksandr Baszłaczow) i ich undergroundowa twórczość - dająca nadzieję, pozwalająca przetrwać lata chylącego się ku upadkowi radzieckiego komunizmu, podczas gdy epoka współczesna proponuje nowy ideał człowieka, jakim jest menedżer, nastawiony na zysk i niepodejmujący buntu konformistyczny przedstawiciel masy. W tym kontekście znamienna jest rozmowa protagonistki z nieco starszym od siebie Tolą:

У нас теперь эпоха попсы. [...] Грядет эра менеджеров, а менеджеры не слушают рок. И в эту эру вам жить!

- А вам?

- А что нам? Мы уже все видели. Это вас мне жалко. Где та молодая шпана, что сотрет нас с лица земли? Ее нет!

Młodsi bracia i siostry tych, których młodość przypadła na czasy pierestrojki, znają już cenę czerpania z życia pełnymi garściami. Ich postawa nie jest zatem ani pogrążaniem się w doczesne rozrywki oferowane przez „magiczny świat konsumpcji”, ani biernym czekaniem na zmianę lub tkwieniem w marazmie w poczuciu braku szans na realizację siebie, co cechowało bohaterów Michaiła Lermontowa, Iwana Turgieniewa czy Iwana Gonczarowa. Odczuwając niepewność jutra - „Мы живем на стыке эпох, приятель. Отсюда хорошо видно, что было когда-то, но кто нам скажет, что будет потом?", bohaterowie omawianego utworu przyjmują postawę kontestacji, pozwalającej odnaleźć „swoją misję w budowaniu własnej tożsamości, odrębnej od tej, jaką próbowali im narzucić rodzice, społeczeństwo, czy państwo" 20 poprzez tworzenie własnej subkultury, zorientowanej na koncepcje ekologiczne, wschodni mistycyzm i rozwój własnego „Ja”. Warto dodać, że kontestacja jest naturalną właściwością subkul-

${ }^{20}$ P. Rudnicki, Oblicza buntu w biografiach kontestatorów. Refleksyjność wyzwalające uczenie się - zmiana, Wydawnictwo Naukowe Dolnośląskiej Szkoły Wyższej, Wrocław 2009, s. 62-63. 
tury, jak bowiem zauważa Mirosław Pęczak, subkultura to „względnie spójna grupa społeczna, wyrażająca swoją odrębność poprzez zanegowanie lub podważenie utrwalanych i powszechnie akceptowanych wzorów kultury" ${ }^{21}$. Zdaniem Tadeusza Palecznego zachowania kontestatorów skierowane są na trzy zespoły celów: (a) dążenie do wywołania zmiany społecznej motywowane poczuciem krzywdy czy dyskomfortu, wynikające $\mathrm{z}$ ograniczeń $\mathrm{w}$ doborze środków umożliwiających dążenie do zaspokajania swoich potrzeb, (b) unikanie zobowiązań nakładanych przez system, niepodporządkowanie się nakazom i zakazom oraz rezygnacja z zajmowanego określonego miejsca w systemie społecznym, (c) poszukiwanie i przyjmowanie alternatywnych, akceptowalnych w wąskim środowisku wzorów i środków działania ${ }^{22}$. W przypadku pokolenia next reprezentowanego przez bohaterów opowieści Stop!... mamy do czynienia z ostatnim z przypadków, kiedy to kontestacja obiera kształt działań alternatywnych w stosunku do głównego nurtu kultury. Jak sugeruje krakowski badacz, alternatywiści

przeważnie nie pragną obalenia systemu ani jego zmiany. Chcą jedynie odnaleźć w nim swoje miejsce, zająć swoistą 'niszę kulturową', zmieścić się w nieokreślonym bliżej obszarze dowolności, w którym mogliby realizować swoje zamierzenia i cele ${ }^{23}$, ponieważ funkcjonowanie $\mathrm{w}$ strukturach zaburzonego „bezpieczeństwa ontologicznego", utożsamianego z poczuciem „trwania i porządku zdarzeń, w tym zdarzeń wykraczających poza obszar bezpośredniego doświadczenia jednostki"24

w sytuacji braku oparcia w świecie szybko dezaktualizujących się wartości, rodzi potrzebę poszukiwania sensu na własną rękę. W opowieści Bogatyriewej alternatywą dla modelu ideałów kapitalistycznych, które mają swoje źródła między innymi w Ame-

${ }^{21}$ M. Pęczak, Mały słownik subkultur młodzieżowych, Wydawnictwo Naukowe Temper, Warszawa 1992, s. 4.

${ }^{22}$ T. Paleczny, Kontestacja. Formy buntu we współczesnym społeczeństwie, Zakład Wydawniczy „Nomos”, Kraków 1997, s. 80-83.

${ }^{23}$ Tamże, s. 83.

${ }^{24}$ A. Giddens, Nowoczesność i tożsamość. „Ja” i społeczeństwo w późnej nowoczesności, przeł. A. Szulżycka, Wydawnictwo Naukowe PWN, Warszawa 2001, s. 314 . 
ryce, jest również zaczerpnięta $\mathrm{z}$ amerykańskiego doświadczenia propozycja oparcia indywidualnej egzystencji na wędrówce, przemieszczaniu się w celu poznania innych i samego siebie. Nie jest to w kulturze rosyjskiej nic nowego - motyw drogi, rozumiany czy to jako dosłowne pokonywanie przestrzeni (a te w Rosji zawsze były bezkresne), czy też jako metaforyczna podróż inicjacyjna i droga do wnętrza siebie oraz proces poznawania istoty rzeczy i prawdy o świecie odnajdujemy w prozie m.in. Aleksandra Radiszczewa, Nikołaja Gogola, Iwana Bunina, Wieniedikta Jerofiejewa i innych ${ }^{25}$. Życie „w drodze” było też kluczowym ideałem przedstawicieli Beat Generation, wędrówka bowiem kojarzona była przez nich $\mathrm{z}$ wiecznym ruchem, a ten $\mathrm{z}$ kolei rozumiany był jako metafora samego życia, dlatego też z koncepcjami bitników wiązać należy początek historii autostopu jako zjawiska utożsamianego z wolnością, wyrzekaniem się schematów, stereotypów i systemu społecznego ${ }^{26}$. Kontestacyjny w swym charakterze motyw przemieszczania się obecny jest, w przekonaniu Tomasza Maślanki, zarówno u klasyków kontrkultury, jak i w pseudognozie:

Toposowi podróży odpowiada figura pielgrzyma-konwertyty oraz idea duchowej metanoi [...] Motyw wewnętrznej duchowej pielgrzymki, alegoria powrotu do samego siebie, idea poszukiwania własnej drogi, prowadzącej do lepszego samorozumienia, mają korzenie zarówno romantyczne, jak i kontrkulturowe ${ }^{27}$.

W omawianej prozie czterodniowa wyprawa, jaką podejmują bohaterowie autostopem, na wschód nad syberyjskie tajemnicze jezioro, może być rozpatrywana jako forma buntu pokolenia next — jest to rodzaj ucieczki od utrwalonych modeli funkcjonowania, sięgająca swymi korzeniami romantyzmu próba doświadczenia egzotyki nowego miejsca oraz forma sprawdzenia własnego charakteru.

\footnotetext{
${ }^{25}$ Zob. np. T. Późniak, A. Wieczorek (red.), Podróż w literaturze rosyjskiej i innych literaturach słowiańskich, WSP im. Powstańców Śląskich w Opolu, Opole 1993.

${ }^{26}$ K. Rydkodym, Krótka historia autostopu, https://plecakwspomnien.pl/2012 /06/krotka-historia-autostopu/ (7.08.2020).

${ }^{27}$ T. Maślanka, Kontrkultura. Źródła i konsekwencje radykalizmu społeczno-kulturowego w perspektywie socjologii kultury, Ośrodek Myśli Politycznej, Kraków 2017, s. 114.
} 
Włóczęgostwo bohaterów należy zatem rozumieć jako „rezygnację z kultury na rzecz pozyskania czystego i pozbawionego celu poznania bytu"28. Zygmunt Bauman wyodrębnił cztery typy osobowości charakterystyczne dla epoki ponowoczesnej: spacerowicza, włóczęgi, turysty i gracza. Bohaterowie Bogatyriewej swoją postawą przypominają Baumanowskiego włóczęgę, dla którego „ruch jest ważniejszy od celu"29. Warto zaznaczyć, że bunt podejmowany przez bohaterów nie ma charakteru aktywnego zrywu - protagoniści nie rzucają jawnego wyzwania systemowi, nie walczą z ustrojem, dominującym stylem życia, ale dokonują indywidualnego wyboru opartego na priorytecie osobistej wolności i niezależności. Tym samym zaakcentowane zostają psychiczne przeżycia jednostki i jej otwartość na świat. Bycie w drodze narzuca bowiem przyjęcie określonej postawy - uczy tolerancji, wymaga szczerości, szacunku względem spotkanego na drodze drugiego człowieka (Innego), brania odpowiedzialności za swoje decyzje, a więc kształtuje umiejętności uniwersalne, przydatne niezależnie od czasu i miejsca. W podróży ważne stają się nie plany i zamierzenia, ale konkretne „tu i teraz” - umiejętność dostrzeżenia chwili w jej ulotnym wymiarze, zwrócenie uwagi na monotonną niekiedy codzienność, na istotę samego życia, które jest nieprzewidywalne, zaskakujące, przynoszące radość, ale również ból, rozczarowanie i cierpienie. Pokonywanie drogi ma wymiar edukacyjny i formuje charakter człowieka - pozwala dostrzec świat w jego różnorodności, wieloaspektowości i bogactwie zjawisk. Przede wszystkim jednak wiąże się z poznaniem samego siebie i podjęciem refleksji nad sensem życia. Nauczycielem w tym procesie staje się wtajemniczony, czyli bardziej doświadczony włóczęga - Gran, znawca dekalogu drogi, który swoją wiedzą i doświadczeniem dzieli się z Miełką, Nastią i Saszą Sorokinem. Droga (zarówno w sensie dosłownym, jak i metaforycznym jako droga życiowa) wymaga m.in. odpowied-

\footnotetext{
${ }^{28}$ Т. Л. Рыбальченко, Сюжет бродяжничества и новая картина мира в современной русской литературе, „Вестник Томского государственного университета. Филология" 2013, nr 6 (26), s. 87.

${ }^{29}$ Zob. Z. Bauman, Ponowoczesne wzory osobowe, „Studia Socjologiczne” 2011, nr 1 (200), s. 450.
} 
niego nastawienia (liczą się takie cechy jak: „жизнерадостность, беззаботность и огромная улыбка") oraz intuicyjnego odbioru otaczającej rzeczywistości, dostrzegania zjawisk na pozór nieuchwytnych i skrytych pod widzialną powierzchnią rzeczy. Uczy oswajania strachu przed nieznanym, konieczności nawiązania utraconego $\mathrm{w}$ toku rozwoju cywilizacyjnego kontaktu z przyrodą, a wyrwanie z miejsc doskonale znanych i oswojonych rodzi pytania o cel i sens życia oraz samej podróży:

Постоянное, постоянное движение без остановок, смена лиц, мест, а их так много, и мест, и лиц, и в чем же тут смысл, в чем же цель - сегодня еду туда, завтра - оттуда, а где же то, куда я в итоге приду?

Ważnym punktem odniesienia dla podejmujących włóczęgę przedstawicieli pokolenia next staje się filozofia buddyjska, która pozwala spojrzeć na rzeczywistość i samego siebie z odmiennej niż dominująca w świecie konsumpcji perspektywy. Oczywiście, stosunek do tej filozofii wśród przedstawicieli pokolenia next jest różnoraki - jedni traktują ją jako modę, za którą należy podążać, inni zaś starają się znaleźć w tym systemie filozoficzno-religijnym drogowskaz etyczny. Pobyt nad tajemniczym syberyjskim jeziorem staje się dla bohaterki okazją do zrozumienia majestatu przyrody i swojego w niej miejsca. Jak zauważa Małgorzata Jacyno,

[...] idealizacja wiejskiego życia i „powrotu do natury”, a nade wszystko odżywająca co jakiś czas w purytanizmie idea konieczności odrodzenia życia duchowego i praktykowania braterskiej miłości przez zaangażowanie się w niezarobkową pracę, to poprzedzające kontrkulturę przejawy niepokoju co do oceny "cywilizacyjnego cudu" ${ }^{\circ}$.

Krytyczne podejście do zdobyczy cywilizacji, której rozwój ignoruje potrzeby człowieka i wtłacza go w utarte schematy kulturowe, nieobce jest współczesnej rosyjskiej prozie - warto w tym kontekście wymienić choćby powieść Natalii Kluczariowej Wagon Rosja (Россия, общзий вагон, 2006). Kluczariowa również wykorzystuje metaforę wrogiego miasta i przyjaznej, choć biednej i wyludnionej, wsi - miejsca, w którym można odnaleźć siebie i odzyskać utra-

\footnotetext{
${ }^{30}$ M. Jacyno, Kultura indywidualizmu, Wydawnictwo Naukowe PWN, Warszawa 2007, s. 30.
} 
coną harmonię. O ile jednak w powieści Kluczariowej bohaterowie (reprezentujący również pokolenie next) zmagają się z wyraźnymi traumami, dla których lekiem jest przyroda i praca, o tyle protagoniści Bogatyriewej pozbawieni są wyraźnych dramatycznych doświadczeń.

Trwająca bez względu na okoliczności przyroda, podlegająca prawom upływu czasu sprawia, że Miełkaja weryfikuje swoje stanowisko wobec wartości, które proponuje jej miasto, odnajdując tym samym sens życia:

Bсе те ценности, что там, в городах, известны, за два месяца трассы потеряли для меня смысл. Заглядывая туда, я видела, как все эти ценности легко выстраиваются в цепочку и объясняют одно другим, я пыталась это проследить: может быть, где-то появится то, ради чего действительно стоит жить, но теряла концы. Учеба - к работе, работа - к деньгам, деньги - к благополучию, семья - к детям, дети... Где конечная цель? Я же теперь знала, что можно жить без денег, без дома, без запасов, главное - излучать радость и быть хорошими людьми. Но, оборачиваясь к миру, я видела, что в нем все устроено иначе, и мне хотелось встать перед всем миром, закрыть глаза и сказать громко: „Стоп!” - чтобы все остановились, а потом задать один-единственный вопрос: зачем?

Refleksja nad porządkiem świata utrwalanym we wzorcach kultury rodzi w bohaterce poczucie pustki - nie jest to jednak pustka egzystencjalna, wynikająca ze znużenia nadmiarem doznań i przyjemności, ale pustka mająca wymiar mistyczny, będąca metaforą prawdy ostatecznej. Pustka ta jest rozumiana zgodnie z filozofią buddyjską — ,jest czymś pozytywnym, związanym z wyzwoleniem i radością, a nie stanem całkowicie pozbawionym sensu" ${ }^{31}$. Pomaga ona wyzbyć się własnego ego i przywiązania do spraw materialnych, które rodzą cierpienie. Czerpanie ze wschodnich koncepcji filozoficznych jako alternatywa dla kultu konsumpcyjnego stylu życia oraz przekonanie, że rzeczywistość ma wymiar iluzoryczny odnajdujemy również $\mathrm{w}$ prozie Wiktora Pielewina, który także poddawał refleksji pokolenie czasów transformacji, tworząc obraz

\footnotetext{
${ }^{31}$ A. Mandrela, Tomistyczna filozofia bytu i buddyjska filozofia pustki, „Rocznik Tomistyczny" 2015, nr 4, s. 219-220.
} 
ludzi „samotnych i zagubionych w trudnym momencie historii, rozpaczliwie poszukujących swojego miejsca w świecie"32.

Analizowany utwór nie przynosi bohaterom gotowych odpowiedzi na nurtujące ich dylematy moralne czy ontologiczne, i choć jego protagonistka pozytywnie ocenia doświadczenie drogi, które otworzyło jej świadomość na otaczającą rzeczywistość, pozwalając lepiej rozumieć świat i jego zmienną istotę („мне кажется, что порой приближаюсь к его разгадке: вдруг будто что-то открывается во мне, все становится кристально ясно, и больше никаких вопросов"), to jednocześnie zdaje sobie sprawę, że jej propozycja, podobnie jak idee bitników, może być zweryfikowana przez czas, który przynosi nowe wyzwania i nowe wzorce („Той Америки, о которой писал Керуак, давно не было: она погибла во Вьетнаме, сгорела от ганжи, обрюзгла и обуржуазилась, набила щеки гамбургерами и уехала в Голливуд”). Kontestacja bowiem łatwo może zamienić się w swoje przeciwieństwo, ulegając naciskom popkultury, czego przyczyną jest m.in. sama natura generacji jako takiej. Jak zauważa Justyna Teodorczyk, „wizja 'betonowego molocha', 'umierających' drzew i bezdusznych 'zewnątrzsterownych ludzkich automatów’ przestała być straszna dla coraz bardziej 'zepsutych' i przedwcześnie 'wydoroślałych' konsumentów"33.

Opowieść Iriny Bogatyriewej, będąca głosem pokolenia next, pozwala ujawnić pęknięcia istniejące wewnątrz społeczeństwa, pokazać, że nie jest ono całkowicie zintegrowane i kulturowo jednorodne, ale funkcjonują $\mathrm{w}$ nim (choć raczej na obrzeżach niż w centrum) grupy, które pragną kształtować własną tożsamość w opozycji do lansowanego przez obowiązujące wzorce modelu. Kontestacja bohaterów utworu Stop!... ma przede wszystkim wymiar psychologiczny, skierowany na odkrycie przez jednostkę głębszych warstw własnej świadomości, oraz społeczny, polegający na wskazaniu możliwości nowych norm, wzorów i zasad postępowa-

\footnotetext{
${ }^{32}$ A. Kuchta, Wiktora Pielewina sny o pustce. „Mały palec Buddy” jako opowieść o pograniczach bytu i nicości, „Maska” 2016, nr 30, s. 112.

${ }^{33}$ J. Teodorczyk, Hipisowska kontestacja lat 60. i 70. XX w. na fali $i$ w pułapce kryzysu. O globalistycznych aspektach subkultury dzieci-kwiatów, „Kultura Historia - Globalizacja” 2011, nr 9, s. 128.
} 
nia, które mogłyby się okazać atrakcyjne dla szerszego grona obywateli i integrować ich wokół pewnego stylu życia.

\section{REFERENCES}

Ankudinov, Kirill. "Chertovo pole eksperimentov." VZGLYAD.RU, 15 July 2007, https://vz.ru/culture/2007/7/15/94305.html. Accessed 4 Aug. 2020 [Анкудинов, Кирилл. “Чертово поле экспериментов.” ВЗГЛЯД.РУ, 15 июля 2007, https://vz.ru/culture/2007/7/15/94305.html. Дата обращения: 4 августа 2020].

Bauman, Zygmunt. "Ponowoczesne wzory osobowe." Studia Socjologiczne, no. 1 (200), 2011: 435-458.

Bogatyreva, Irina. "Stop! ili Dvizheniye bez ostanovok. Zhurnal'nyy wariant." https://royallib.com/book/bogatireva_irina/Stop_ili_dvigenie_bez_ostanovok_gurnalniy_variant.html. Accessed 5 Aug. 2020 [Богатырева, Ирина. "Stop! или Движение без остановок. Журнальный вариант." https://royallib.com/book/bogatireva_irina/Stop_ili_dvigenie_bez_ostanovok_gurnalniy_variant.html. Дата обращения: 5 августа 2020].

Duda, Katarzyna A. Szkice o prozie rosyjskiej XXI wieku: Ulicka, Szyszkin, Pielewin, Minajew, Sienczyn, Kuricyn, Starobiniec... Kraków: Księgarnia Akademicka, 2017.

Duda, Katarzyna. “'Nowi Rosjanie’ i statystyczny obywatel. Współczesna Rosja w literaturze popularnej (Oksana Robski i Wiktoria Tokariewa)." Kultura rosyjska $w$ ojczyźnie i diasporze. Ksiegga jubileuszowa dedykowana profesorowi Lucjanowi Suchankowi. Vol. 2. Ed. Duda, Katarzyna. 201-210. Kraków: Wydawnictwo Uniwersytetu Jagiellońskiego, 2008.

Duda, Katarzyna. "Nowy Rosjanin w przestrzeni miasta-metropolii." Politeja, no. 39, 2015: 329-344.

Giddens, Anthony. Nowoczesnosśc i tożsamość. "Ja" $i$ społeczeństwo w późnej nowoczesności. Transl. Szulżycka, Anna. Warszawa: Wydawnictwo Naukowe PWN, 2001.

Godlewski, Grzegorz. "Animacja i Antropologia." Animacja Kultury. Doświadczenie i przyszłość. Ed. Godlewski, Grzegorz, et al. 56-69. Warszawa: Instytut Kultury Polskiej UW, 2002.

Jacyno, Małgorzata. Kultura indywidualizmu. Warszawa: Wydawnictwo Naukowe PWN, 2007.

Jawłowska, Aldona. Drogi kontrkultury. Warszawa: Państwowy Instytut Wydawniczy, 1975.

Jesiotr, Katarzyna. “W drodze’ na Zachód. Między metafizyczną wędrówką Jarosława Markiewicza a deliryczną podróżą Wieniedikta Jerofiejewa, czyli o związkach literatury pisarzy byłego bloku wschodniego z twórczością 'pobitego pokolenia' Ameryki." https://depot.ceon.pl/bitstream/han- 
dle/123456789/15814/Katarzyna\%20Jesiotr.pdf? sequence=1\&isAllowed=y. Accessed 5 Aug. 2020.

Kalita, Liliana. "Kreowanie własnego wizerunku przedstawiciela rosyjskiej klasy średniej (na materiale powieści Siergieja Minajewa 'The Telki. Povest' o nenastoyashchey lyubvi')." ["Kreowanie własnego wizerunku przedstawiciela rosyjskiej klasy średniej (na materiale powieści Siergieja Minajewa 'The Телки. Повесть о ненастоящей любви')."] Socjolingwistyczne badania w teorii i praktyce. Ujęcie interdyscyplinarne. Vol. 1. Ed. Mampe, Joanna, Owczinnikowa, Łada. 47-56. Gdańsk: Wydawnictwo Uniwersytetu Gdańskiego, 2014.

Kamińska, Paulina. "7 zasad strategii marketingowej, czyli jak skutecznie poskromić milenialsów." http://adnext.pl/onas/7-zasad-strategii-marketingowejczyli-jak-skutecznie-poskromic-milenialsow-2/. Accessed 2 Aug. 2020.

Kuchta, Anna. "Wiktora Pielewina sny o pustce. 'Mały palec Buddy' jako opowieść o pograniczach bytu i nicości." Maska, no. 30, 2016: 111-121.

Mandrela, Anna. “Tomistyczna filozofia bytu i buddyjska filozofia pustki." Rocznik Tomistyczny, no. 4, 2015: 215-238.

Maślanka, Tomasz. Kontrkultura. Źródła i konsekwencje radykalizmu społeczno-kulturowego w perspektywie socjologii kultury. Kraków: Ośrodek Myśli Politycznej, 2017.

Paleczny, Tadeusz. Kontestacja. Formy buntu we wspótczesnym społeczeństwie. Kraków: Zakład Wydawniczy „Nomos,” 1997.

Pawletko, Beata. "Nowi Rosjanie’ w krzywym zwierciadle literatury (na przykładzie prozy Władimira Tuczkowa)." Antropologia kultury mieszczańskiej. Ed. Ławnikowska-Koper, Joanna, Rożek, Lucyna. 193-204. Częstochowa: Akademia im. Jana Długosza w Częstochowie, 2016.

Pęczak, Mirosław. Mały słownik subkultur młodzieżowych. Warszawa: Wydawnictwo Naukowe Temper, 1992.

Podróż w literaturze rosyjskiej i innych literaturach słowiańskich. Ed. Późniak, Telesfor, Wieczorek, Aleksandra. Opole: WSP im. Powstańców Śląskich w Opolu, 1993.

Prasek, Cezary. Złota młodzież PRL i jej obraz w literaturze i filmie. Warszawa: Bellona, 2010.

Rudnicki, Paweł. Oblicza buntu w biografiach kontestatorów. Refleksyjność - wyzwalające uczenie się - zmiana. Wrocław: Wydawnictwo Naukowe Dolnośląskiej Szkoły Wyższej, 2009.

Rybal'chenko, Tat'yana L. "Syuzhet brodyazhnichestva i novaya kartina mira v sovremennoy russkoy literature." Vestnik Tomskogo gosudarstvennogo universiteta. Filologiya, no. 6 (26), 2013: 87-100 [Рыбальченко, Татьяна Л. “Сюжет бродяжничества и новая картина мира в современной русской литературе." Вестник Томского государственного университета. Филология, № 6 (26), 2013: 87-100].

Rydkodym, Kuba. "Krótka historia autostopu." https://plecakwspomnien.pl/2012/06/krotka-historia-autostopu/. Accessed 7 Aug. 2020.

Skotnicka, Anna. “Obraz 'novogo russkogo' v sovremennoy proze." [“Образ ‘нового русского' в современной прозе.” ] Wielkie tematy kultury w literatu- 
rach słowiańskich. Pieniądz. Ed. Chrobak, Katarzyna, et al. 225-233. Wrocław: Wydawnictwo Uniwersytetu Wrocławskiego, 2009.

Stachowska, Sylwia. "Oczekiwania przedstawicieli pokolenia Y wobec pracy i pracodawcy." Zarządzanie Zasobami Ludzkimi, no. 2 (85) (2012): 33-56, http:// www.ipiss.com.pl/wp-content/uploads/downloads/2015/01/ZZL_2-2012_ Stachowska-S_33-56.pdf. Accessed 2 Aug. 2020.

Szmyd, Jan. "Nowoczesny konsumpcjonizm - zmiana kondycji ludzkiej i jakości życia. Wyzwania społeczne i pedagogiczne." Kultura - Przemiany - Edukacja, vol. 5, 2017: 13-36.

Taplin, Phoebe. "The Russian Kerouacs: Irina Bogatyreva's guide to hitchhiking." The Calvert Journal, 28 Aug. 2013, https:/www.calvertjournal.com/articles/ show/1350/rise-of-the-russian-kerouacs-hitchhiking. Accessed 5 Aug. 2020.

Teodorczyk, Justyna. "Hipisowska kontestacja lat 60. i 70. XX w. na fali i w pułapce kryzysu. O globalistycznych aspektach subkultury dzieci-kwiatów." Kultura Historia - Globalizacja, no. 9, 2011: 123-130.

Tumblr. "Milenialsi, generacja Z... Skąd wiadomo, do którego pokolenia się należy?” https://www.polityka.pl/tygodnikpolityka/ludzieistyle/1654918,1,mile nialsi-generacja-z-skad-wiadomo-do-ktorego-pokolenia-sie-nalezy.read. Accessed 2 Aug. 2020.

Walków, Marcin. "Pokolenia na rynku pracy w Polsce - kim są baby boomers, X, Y i C?” https://businessinsider.com.pl/rozwoj-osobisty/kariera/millenialspokolenie-X-y-z-i-baby-boomers-kim-sa-na-rynku-pracy/6e53lmr. Accessed 2 Aug. 2020.

Wołodźko-Butkiewicz, Alicja. Od pieriestrojki do laboratoriów netliteratury. Przemiany we współczesnej prozie rosyjskiej. Warszawa: Studia Rossica, 2004.

Zhuchkova, Anna V. "Bogatyrskaya proza I. Bogatyrevoy. Eklektika zhanra." Vestnik slavyanskikh kul'tur, vol. 50, 2018, http://www.vestnik-sk.ru/russian/ archive/2018/tom-50/zhuchkova. Accessed 4 Aug. 2020 [Жучкова, Анна В. “Богатырская проза И. Богатыревой. Эклектика жанра." Вестник славянских культур, т. 50, 2018, http://www.vestnik-sk.ru/russian/archive/2018/tom-50/zhuchkova. Дата обращения: 4 августа 2020].

Zywert, Aleksandra. "Jak się bawią nieprawdziwi ludzie? (Sergiej Minajew, 'Duchless')." Czas wolny, rozrywka, używki w najnowszej literaturze rosyjskiej. Ed. Kalita, Liliana. 53-68. Gdańsk: Wydawnictwo Uniwersytetu Gdańskiego, 2018.

Zywert, Aleksandra. "Literacki obraz Nowych Rosjan.” Roczniki Humanistyczne, vol. 66, no. 7, 2018: 125-138. 